\title{
Relativização de direitos fundamentais: uma abordagem a lume da necessidade da adoção de um tratamento constitucional penal diferenciado face à expansão desenfreada da criminalidade organizada
}

\author{
Fabiana Greghi ${ }^{1}$ \\ Eduardo Diniz Neto ${ }^{2}$
}

\begin{abstract}
Resumo
Devido à complexidade e ao caráter multiforme da criminalidade organizada, 0 tratamento penal tradicional dispensado para a repressão da criminalidade individualizada é inócuo para o seu tratamento. Neste contexto é que surge o fio condutor do presente artigo, qual seja, o enfoque da relativização de alguns dos direitos fundamentais constitucionais como forma de viabilizar a contenção da delinqüência organizada, e conseqüentemente, a pacificação social. A relevância da problemática a ser exposta dá-se em razão da inexistência de direitos que possam ser concebidos como absolutos ou ilimitados. Os direitos fundamentais gozam de certa relatividade em razão da necessidade de se amparar outros direitos fundamentais. E é justamente neste cenário abarcado pela relativização de certos direitos que se busca conferir efetividade ao sistema penal, tornando-o apto para a desarticulação da estrutura cada vez mais desafiante da delinqüência organizada.
\end{abstract}

Palavras-Chave: Criminalidade Organizada; Direitos Fundamentais; Relativização.

\section{Introdução}

No que diz respeito à criminalidade, o maior desafio contemporâneo concentra-se em alcançar maneiras eficazes de reprimir o crime organizado.

Não obstante a atual realidade social marcada pelos avanços tecnológicos possibilitar uma melhor qualidade de vida, suscita também novas formas delituosas organizadas que apostam na impunidade para aniquilar a ordem e a segurança pública, maculando desta forma o Estado Democrático de Direito.

Vivemos numa sociedade sinalizada pela globalização, que ao mesmo tempo em que oferece subsídios para um intenso fluxo econômico, político, social e cultural, recrudesce o fenômeno da criminalidade organizada.

1 Bacharel em Direito pela Universidade Estadual de Londrina e Pós-graduanda do curso de Especialização em Direito e Processo Penal da Universidade Estadual de Londrina. E-mail: fabianagreghi@hotmail.com. Telefone para contato: (43) 33278934 ou (43) 91288934.

2 Mestre em Ciências jurídico-criminais pela Universidade de Coimbra- Portugal, Promotor de justiça, e professor na Universidade Estadual de Londrina e na Fundação Escola do Ministério Público do Estado do Paraná- FEM PAR. 


\section{Relativização de direitos fundamentais: uma abordagem a lume da necessidade da adoção de um tratamento constitucional penal diferenciado face à expansão desenfreada da criminalidade organizada}

Com a globalização, a análise da delinqüência muda de foco: os delitos do paradigma clássico do processo de criminalização perdem espaço para os delitos classificados criminologicamente como crimes of the powerful.

Estes crimes caracterizam-se pelo portentoso grau de ofensividade à paz pública, merecendo pois um tratamento penal e processual penal diferenciado do dispensado à criminalidade comum. Mesmo porque, a criminalidade organizada escarnece dos instrumentos penais tradicionais utilizados para o trato da delinqüência individualizada, que se mostram defasados ante o seu caráter multiforme. E de outro modo não poderia ser, já que é ilógico tentar combater coisas distintas valendo-se de um único método, ou seja, é irracional a aplicação de um mesmo aparato para a contenção de criminalidades abissalmente diversas.

Mister se faz anotar que o presente artigo não tem a pretensão de esgotar de forma alguma a temática. Muito pelo contrário. Objetiva-se com o auxílio dos pontos de vista de renomados estudiosos, fomentar ainda mais a discussão acerca do intrigante e complexo tema a ser abordado.

\section{O fenômeno da criminalidade organizada}

Antes de adentrar na temática a que este artigo se propõe, salutar é desenvolver breves considerações acerca do fenômeno da criminalidade organizada. Para tanto, imprescindível que se perquira as características peculiares do crime organizado que justificam o emprego de um tratamento constitucional penal diferencido daquele dispensado à criminalidade individualizada.

De acordo com os romanos, initium doctrinae sit consideratio nominis, isto é, a doutrina deve iniciar o estudo de determinado assunto pelo nome. Portanto, de extrema relevância é a conceituação do crime organizado, uma vez que a aplicação de um novel tratamento constitucional penal fulcrado na relativização de direitos fundamentais, protagonista deste artigo, visa ao seu combate.

O legislador brasileiro omitiu-se e deixou a árdua tarefa da definição do crime organizado a cargo da doutrina e da jurisprudência.

Perdeu-se a oportunidade de delimitar o que seja crime organizado com a edição da Lei $9.034 / 1995$ e sua posterior alteração pela Lei 10.217/2001. Até hoje o ordenamento 
jurídico brasileiro encontra-se desprovido de qualquer contorno ou alusão ao conteúdo da criminalidade organizada. No dizer de Luiz Flávio Gomes, "continuamos legislativamente sem saber o que é que devemos entender por crime organizado (strictu senso), dentro da extensa realidade fenomenológica criminal". (GOM ES; CERVINI, 1997, p. 89)

Diante do déficit conceitual imposto pelo legislador, não restou outra alternativa a não ser o estudo cada vez mais apurado na busca de se revelar o perfil do crime organizado, haja vista a impossibilidade de reprimir eficientemente o que se desconhece.

Feitas essas ponderações, para que se possa entender a estrutura do crime organizado, passa-se a buscar a caracterização das organizações criminosas disseminada pela doutrina, em virtude da carência de uma definição legal clara e precisa a respeito do fenômeno criminal em estudo.

Uma das mais notáveis características das organizações criminosas é a estrutura hierárquico-piramidal que possuem. Arquiteturam-se como se fossem verdadeiras empresas obstinadas a acompanharem as leis do mercado, oferecendo o que é ilícito para promoverem atividades proibidas, obtendo, assim, lucros fabulosos.

Nota constitutiva desse vínculo hierárquico é a impessoalidade da organização, que inclusive a aproxima de uma sociedade anônima. Não se externa a composição das organizações, muito pelo contrário, o conteúdo e o seu funcionamento só são sabidos internamente. Isso acaba por dificultar e muito a obtenção de provas e o desmantelamento da organização, mesmo porque, geralmente os membros que são alcançados estão na base da pirâmide e são, depois de capturados, facilmente substituídos por outros, não abalando, de modo algum, a estrutura e liderança das associações criminosas.

Outro ponto característico é a divisão de tarefas entre os componentes das organizações criminosas.

Raúl Cervini, em primoroso estudo, salienta que as organizações criminosas constituem-se de coordenação, consistente na unidade de decisão operativa, estabelecendo-se uma relação de subordinação e ajuda mútua entre os diferentes segmentos que integram o grupo criminoso. Ao mesmo tempo em que existe uma divisão de trabalho, há em jogo uma comunhão de interesses, com a interdependência entre seus membros para obterem a maior receita possível com a realização dos crimes. (CERVINI; GOMES, 1997, p. 221). 


\section{Relativização de direitos fundamentais: uma abordagem a lume da necessidade da adoção de um tratamento constitucional penal diferenciado face à expansão desenfreada da criminalidade organizada}

Cada indivíduo tem sua tarefa previamente definida, de forma a especializar a prestação de serviços e elevar a sua eficácia.

Em suma, na associação criminosa há uma equipe voltada para as atividades ilícitas que detém hierarquia própria e capacidade de planejamento empresarial, a qual tem como viga mestra a divisão de trabalho.

Característica muito peculiar e que até mesmo é condição de manutenção das organizações criminosas é a restrição de seus membros. Não é qualquer pessoa que pode ser aceita para compor os quadros das associações criminosas. Deve-se ter cautela e acuidade na seleção dos seus membros para obstar a admissão de pessoas despreparadas, ou pior, a convocação de agentes da polícia que se infiltram nas organizações para desbaratá-las.

As organizações criminosas também ostentam elevado poder de cooptação e corrupção. Os agentes públicos, corrompidos pelo crime, ou participam efetivamente das atividades criminosas, ou viabilizam a execução delas, acobertando os demais criminosos para que não sejam desmascarados e punidos.

Como bem enfatizou Hassemer (1994, p. 63), a criminalidade organizada:

Não é apenas uma organização bem feita, não é somente uma organização internacional, mas é, em última análise, a corrupção da Legislatura, da Magistratura, do Ministério Público, da Polícia, ou seja, a paralisação estatal no combate à criminalidade [...].

Não se pode deixar também de anotar que as organizações criminosas existem preponderantemente para a obtenção de lucros fáceis. Raramente ter-se-á uma organização sem fim empresarial ou econômico, já que a criminalidade organizada se orienta em busca de renda e de poder. Óbvio que podem existir, dentre outros, interesses políticos ou religiosos, porém, em muito menor escala.

Segundo a pesquisa de Eduardo Araujo da Silva (2003, p. 28), estima-se que 0 mercado envolvendo todas as espécies de delinqüência organizada seja responsável por mais de $1 / 4$ (um quarto) do dinheiro em circulação em todo 0 mundo. Matéria publicada nos jornais The Los Angeles Times e no Estado de S. Paulo mostrou que as organizações transnacionais movimentam anualmente cerca de US\$ 850 bilhões. Ainda, segundo a 
Organização das Nações Unidas, só a renda obtida pelo tráfico de entorpecentes (cerca de US\$ 400 milhões) corresponde a $8 \%$ da renda do comércio internacional.

Outro traço peculiar é o domínio territorial. Uma organização criminosa para estar bem sedimentada em um território precisa ter o domínio sobre ele. Claro que na medida em que cresça, poderá desbravar outros espaços, tanto os neutros quanto os já dominados por outra organização. Nessa última hipótese, provavelmente haverá o desencadeamento de um conflito, afinal, cada organização zela por sua soberania e não permite que outra se imiscua em sua zona de atuação.

As associações criminosas organizadas, via de regra, também apresentam uma considerável sofisticação nos seus meios operacionais. Utilizam-se de meios informáticos e de telecomunicação que, na maioria das vezes nem mesmo o Estado detém, e sobre os quais, até desconhece a existência.

O desenvolvimento tecnológico conquistado pelas organizações visa a impedir a colheita de provas, uma vez que o Estado, desmuniciado ou carente de toda essa tecnologia, fica longe de ter êxito na persecução penal.

0 alto poder de intimidação é outro fator característico que merece ser considerado. A "lei do silêncio" (denominada pelos italianos de omertà) é imposta aos integrantes das organizações, bem como a pessoas estranhas a elas, sendo mantida por meio das mais desumanas e violentas artimanhas contra aqueles que desafiam desrespeitálas ou contra seus familiares, com a intenção de intimidar o testemunho, a delação e outras atitudes que possam culminar no desbaratamento das organizações.

Outra das características do crime organizado, notadamente presente nos dias atuais, é a sua internacionalização. Isso decorre do fato de os criminosos, na seara internacional, não se defrontarem com impedimentos para se integrarem, principalmente depois do processo de globalização que facilitou a comunicação a grandes distâncias, ocasionando o envolvimento de diversas organizações com outras de regiões diferentes.

Cumpre destacar que as características aqui atribuídas às organizações criminosas são meramente exemplificativas, dado o dinamismo e conseqüente mutação das mesmas. Convém frisar ainda que não é preciso estarem esses atributos cumulativamente presentes para a existência de uma associação ilícita organizada. Cada caso tem suas peculiaridades. 


\section{Relativização de direitos fundamentais: uma abordagem a lume da necessidade da adoção de um tratamento constitucional penal diferenciado face à expansão desenfreada da criminalidade organizada}

Pois bem, diante dos atributos ínsitos ao crime organizado aqui tratados que 0 diferenciam da criminalidade de massa, urge a adoção de estratégias diferenciadas para que ele possa ser satisfatoriamente combatido.

Neste contexto é que surge a relativização de certos direitos fundamentais como único, desafortunadamente, mecanismo jurídico eficaz na repressão da criminalidade organizada, já que não se pode reprimir crimes tão acentuadamente diversos com os mesmos instrumentos jurídicos.

\section{Necessidade de um tratamento constitucional penal diferenciado para o trato com a criminalidade organizada: relativização de direitos fundamentais}

Pois bem, diante da sofisticação da atuação dos grupos criminosos organizados, 0 tratamento dado à criminalidade individualizada sob a égide do denominado direito penal clássico mostra-se inapto para a contenção do crime organizado.

Os instrumentos jurídicos são os mesmos que serviam a uma ordem social e jurídica profundamente diversa. Isto provoca um descompasso entre os mecanismos jurídicos e a realidade sobre a qual atuam. Enquanto aqueles prosseguem calcados em critérios de pessoalidade, em tipos penais fechados e em sanções corporais, as relações sociais são crescentemente complexas e impessoais.

Para ilustrar o que foi dito, conveniente é mencionar a metáfora proposta por Luiz Flávio Gomes (2002, p. 34). Valendo-se da imagem do elefante e do rato, ele diz que o tradicional direito penal é, em termos de velocidade, um verdadeiro elefante porque se baseia na pena privativa de liberdade e exige conseqüentemente, o devido processo legal clássico: investigação burocratizada, denúncias, provas, instrução demorada, contraditório, ampla defesa, sentença, recursos, etc. Ao passo que a criminalidade da era pós-industrial, e mais recentemente, da globalização, é velocíssima, tanto quanto os ratos. Impossível, pois, conter o rato (criminalidade organizada) com a lentidão do elefante (direito penal clássico).

Em outros termos, os instrumentos penais tradicionais utilizados para o combate da criminalidade individualizada são inócuos para o trato da criminalidade organizada. Conforme $o$ apontamento de Jeffrey Robinson (2001, p. 19): 
Enquanto vivermos num mundo onde uma filosofia de soberania do século XII é reforçada por um modelo judiciário do século XVIII, defendido por um conceito de combate ao crime do século XIX que ainda está tentando chegar a um acordo com a tecnologia do século XX, o século XXI pertencerá aos criminosos.

Não se quer aqui defender a instauração de um Direito Penal de Emergência ou de Exceção. Somente se pretende demonstrar que o direito penal clássico, seus princípios e métodos de investigação apresentam-se defasados para a contenção da delinqüência organizada.

A par disso, o Estado deve encontrar uma reação proporcional à ameaça produzida à sociedade pelas organizações criminosas, sob pena de se frustrar uma de suas funções primordiais, qual seja, a de dirimir conflitos e proporcionar a pacificação social, para além da proteção eficaz de bens jurídicos.

Nesse diapasão, nada mais lógico e indispensável que a adoção de tratamento diverso para cada uma das diferenciadas categorias de criminalidade.

Francisco de Assis Toledo (1995, p. 202-203) defendia que para "crimes de especial severidade", atos de grande violência em que se empregassem meios cruéis, deveria haver um tratamento penal também especial, "sem se cair na radicalização da Lei de Crimes Hediondos", a qual ele considerava excessiva. O saudoso ministro do Superior Tribunal de Justiça militava por uma política criminal diferente para cada espécie de delito, pois, há bens jurídicos variados sob proteção.

Da própria Constituição Federal infere-se que há a possibilidade de tratamentos distintos conforme a gravidade das formas delituosas. No seu artigo 50, inciso XUII, por exemplo, previu que:

A lei considerará crimes inafiançáveis e insuscetíveis de graça ou anistia a prática de tortura, o trafico ilícito de entorpecentes e drogas afins, o terrorismo e os definidos como crimes hediondos, por eles respondendo os mandantes, os executores e os que, podendo evitá-los, se omitirem.

Assim, deu tratamento mais severo aos crimes elencados no aludido dispositivo, ao vedar aos mesmos a fiança, a graça ou anistia. Em contrapartida, em seu artigo 98, ao disciplinar a criação dos juizados especiais, estatuiu uma outra modalidade de crime, a denominada infração penal de menor potencial ofensivo, que recebeu um tratamento mais 


\section{Relativização de direitos fundamentais: uma abordagem a lume da necessidade da adoção de um tratamento constitucional penal diferenciado face à expansão desenfreada da criminalidade organizada}

brando se comparado com os demais delitos. A Lei Maior fez bem em distinguir a criminalidade de alta reprovação da criminalidade média ou pequena.

Aliás, essa é a tendência do direito processual penal na atualidade. Tem sido diferente o tratamento conferido às variadas espécies de criminalidade, representativo de um movimento pendular proporcionalmente justo, por mais pleonástica que possa soar propositadamente a expressão.

Para os crimes tidos como "leves", além de intenso impulso no sentido de serem eliminados do ordenamento ou transformados em infrações administrativas, buscam os sistemas legais, soluções destinadas a:

Evitar a instauração do processo, pela elevação no elenco dos crimes dependentes de representação ou pela solução do conflito através da transação penal entre 0 suspeito e o órgão acusatório;

Impedir a imposição de pena, com suspensão do processo sob condição e posterior extinção da punibilidade;

Evitar a cominação de pena privativa de liberdade, com a previsão de penas substitutivas ou alternativas;

Possibilitar ao réu o não cumprimento em cárcere da pena privativa, mediante suspensão condicional da pena. (FERNANDES, 2005, p. 23-24.).

Scarance Fernandes (2005, p. 24) acrescenta ainda que para a criminalidade convencional há a manutenção do sistema acusatório tradicional, com vastas garantias ao réu, prisão processual excepcional e sistema progressivo de pena.

Já a criminalidade organizada apresenta-se como um enorme desafio ao legislador, o qual se vê diante de um inquietante dilema ao ter de criar um sistema repressivo eficiente e concomitantemente conjugá-lo com os direitos e garantias individuais asseguradas na Constituição.

Pela problemática que representa, é incontestável a necessidade de maior esmero e tempo na dedicação à criminalidade estruturada e organizada, abrindo-se com isso espaço para a resolução célere e simplificada de processos concernentes a infrações de menor lesividade ("de menor potencial ofensivo"). A propósito, esse é o caminho trilhado pela Lei 9.099/1995, dos Juizados Especiais Criminais, ao guiar-se pelos princípios da oralidade, informalidade, simplicidade, celeridade, concentração, imediatismo e da economia processual. Tratando com rapidez a vultosa massa de infrações menores, restará precioso tempo para que a Justiça cuide com mais afinco da criminalidade organizada. 
Além de reclamar maior atenção por parte do legislador, a criminalidade organizada para que possa ser combatida satisfatoriamente, exige o desenvolvimento de estratégias diferenciadas para a sua apuração.

Desse entendimento compartilha Maria Dolores Delgado García (apud SILVA, 2003, p.41), para a qual:

A criminalidade organizada, especialmente a narcocriminalidade, tem evoluído extraordinariamente nos últimos tempos, adquirindo estruturas complexas que dispõem de ingentes meios financeiros de origem ilícita e cuja capacidade operativa supera as das clássicas organizações de delinqüentes, razão pela qual os meios tradicionais de investigação se mostram insuficientes, ao menos para chegar ao coração das organizações e aproximar-se dos seus chefes e promotores.

Depreende-se, portanto, que o sistema penal, tal como foi idealizado para a criminalidade de massa, não é instrumento apropriado para o controle do crime organizado. Afinal, respalda-se na responsabilidade individual, que é pouco adequada para conter a criminalidade de pessoas jurídicas; o Direito Penal da culpa é incompatível com a punição das organizações; a individualização da pena torna-se muito difícil diante das grandes associações comandadas por planejadores que nunca aparecem; os crimes de perigo concreto ou de lesão são refutados para a criminalidade organizada firmada em riscos abstratos; a taxatividade dos tipos penais é contestada como válida para a moderna e complexa criminalidade; o Direito Penal clássico é repressivo e o correto é reagir preventivamente contra o crime organizado (HASSEM ER, 1993, p. 93).

Deste modo, não é difícil entender o porquê da defasagem do tradicional tratamento criminal e punitivo ante à criminalidade organizada. Além dos motivos que a justificam anteriormente indicados segundo a visão de Hassemer, outros tantos podem ser apontados:

1. A impessoalidade das organizações criminosas, isto é, a ausência de contornos definidos em relação a seus membros, dificulta que a atuação deles, assim como as conseqüências de suas ações sejam rastreadas, comprovadas e devidamente punidas;

2. A criminalidade organizada é menos visível que a criminalidade massificada, uma vez que não atinge pessoas certas e determinadas, possui danosidade difusa. Perfaz-se como obstáculo para a reparação dos danos que causa, já que, no momento em que se toma 


\section{Relativização de direitos fundamentais: uma abordagem a lume da necessidade da adoção de um tratamento constitucional penal diferenciado face à expansão desenfreada da criminalidade organizada}

conhecimento das infrações, os danos são imensos e irreparáveis, em virtude da morosidade e falta de traquejo da Justiça em desmantelar as organizações criminosas;

3. A sólida estrutura do crime organizado aliada ao seu caráter multifacetado e adaptativo repercute na moderna dogmática penal, pois se percebe que o tradicional processo de tipificação é obsoleto para tutelar o complexo e variado número de condutas que compõem a criminalidade organizada;

4. O intitulado crime organizado se dedica a impedir a obtenção da prova, dificultando ainda mais o êxito nas investigações destinadas a responsabilização penal de seus componentes. Segundo Elvio Fassoni, há uma verdadeira "cultura da supressão da prova", a qual pode ser evidenciada nas atitudes dos criminosos contemporâneos: a arma disparada para matar alguém é destruída, para evitar comparações com outros episódios de fogo; o automóvel utilizado não é apenas roubado, mas incendiado, para não deixar vestígios; 0 assassino proveniente de muito longe, é desconhecido no ambiente onde age; os suspeitos procuram álibis convincentes e agem por meio de terceiros; os telefonemas dos seqüestradores não duram mais tanto tempo para não permitir a identificação de sua origem; as fontes testemunhais, quando existem, são intimidadas; no interior das organizações criminosas as informações são restritas, para obstar danos oriundos de um possível dissociado (SILVA, 2003, p. 42);

5. 0 uso de meios tecnológicos sofisticados, no mais das vezes melhores dos que os da Polícia, realça a discrepância entre a estrutura dos órgãos oficiais encarregados da persecução penal e a das organizações criminosas;

6. 0 alto poder de intimidação também embarga a produção de prova em face do crime organizado. Diante do temor da vingança, dificulta-se a obtenção da prova oral nas investigações criminais e processos penais que a envolvam (SILVA, 2003, p. 42).

É neste sentido, portanto, que se faz necessária a restrição de certos direitos fundamentais dos acusados que se dá, por exemplo, por meio da quebra do sigilo bancário e fiscal, interceptação das comunicações ambientais e telefônicas, na tentativa de se conquistar maior eficiência penal ante a inadequação do sistema penal clássico em sede de delinqüência organizada.

Com efeito, como as garantias e direitos fundamentais do cidadão, a ordem e a segurança pública também estão insculpidas no texto constitucional (artigos 5ำ, 60 e 144 da 
Constituição Federal) e não podem ser sacrificadas em virtude de uma concepção simplesmente individualista. Além do que, conforme já mencionado, nenhum direito pode ser entendido como absoluto ou ilimitado. Os direitos fundamentais gozam de certa relatividade em razão da necessidade de se resguardar outros direitos fundamentais.

A festejada jurista Ada Pellegrini Grinover comunga deste posicionamento. Para ela:

Os direitos do homem, segundo a moderna doutrina constitucional, não podem ser entendidos em sentido absoluto, em face da natural restrição resultante do princípio da convivência das liberdades, pelo que não se permite que qualquer delas seja exercida de modo danoso à ordem pública e às liberdades alheias (FERNANDES; GOMES FILHO; GRINOVER, 2001, p. 129).

Por não serem absolutos, verifica-se que os direitos fundamentais podem se contradizer, sem que isso faça qualquer um deles perder a sua validade jurídica ou ser derrogado. É exatamente numa situação em que haja confronto entre direitos que 0 princípio da proporcionalidade ganha destaque e é utilizado como critério para solucionar da melhor maneira o conflito, de modo a otimizar o conteúdo do direito que se acata prioritariamente e desatender o mínimo possível do outro.

Inclusive, é nessa perspectiva o magistério de Jesús-María Silva Sánchez (2002, p. 103-104), para quem, frente ao fenômeno da criminalidade organizada é ingente que algumas garantias sejam "reinterpretadas", razão pela qual, nos dias atuais, entende inevitável reformas antigarantistas para a apuração de certas formas de crime.

A propósito, o que se deve discutir não é a possibilidade de o Estado restringir direitos fundamentais, e sim, em que extensão essa restrição pode ocorrer sem que se torne uma medida inconstitucional.

Daí se conclui que o grande paradoxo do sistema penal é a convivência entre suas duas finalidades primordiais: a eficácia na realização da justiça e a proteção dos direitos fundamentais do cidadão. Diante da impossibilidade de integral harmonia entre elas logrouse atingir na maioria dos Estados Democráticos de Direito aquilo que Jorge de Figueiredo Dias chama de "concordância prática" dessas finalidades em conflito, "de modo que de cada uma se salve, em cada situação o máximo conteúdo possível, otimizando os ganhos e minimizando as perdas axiológicas e funcionais" (FIGUEIREDO DIAS, 2006, p. 249). 


\section{Relativização de direitos fundamentais: uma abordagem a lume da necessidade da adoção de um tratamento constitucional penal diferenciado face à expansão desenfreada da criminalidade organizada}

Realmente, a busca por um ponto de equilíbrio entre o conflito de interesses estatais (controle e repressão da criminalidade) e os direitos individuais na apuração da delinqüência organizada se mostra como um dos maiores desafios da ordem jurídico-penal contemporânea, dada sua latente tensão dialética.

Nesse impasse duas alternativas se levantam: ou se defende 0 absolutismo dos direitos fundamentais ou se minimiza a sua rigidez. A primeira opção, claramente mais cômoda, inviabiliza, sobretudo na seara da criminalidade organizada, a regularidade e a eficácia do processo penal. A segunda, indubitavelmente é a mais árdua, mas também é a que de fato proporciona uma produtiva repressão à delinqüência.

Sob este ponto de vista, é pertinente a restrição de certos direitos de indivíduos pertencentes a organizações criminosas que vilipendiam os direitos fundamentais da sociedade. E não há como cogitar a inconstitucionalidade ao se limitar o exercício de direitos fundamentais. A própria Lei Maior prevê inúmeras circunstâncias em que esses direitos sofrem restrições. A título exemplificativo pode ser citado o art. 5ํ, XI da Constituição Federal, que admitiu a violabilidade do domicílio em caso de flagrante delito ou desastre, ou para prestar socorro, ou, durante o dia, por determinação judicial, apesar de ter consagrado, em regra, a sua inviolabilidade.

Outrossim, esse equilíbrio outrora alcançado entre a necessidade de uma administração da Justiça Criminal eficaz e a observância das garantias fundamentais do cidadão vem se revelando precário, frente aos novos fenômenos da atualidade, notadamente 0 da criminalidade organizada. Logo, hodiernamente impõe-se um Direito Penal que não seja somente um "ordenamento de liberdade", limitativo do poder-dever de punir estatal, mas igualmente um "ordenamento de segurança", ampliativo dos poderes estatais em prol do resguardo dos direitos fundamentais dos cidadãos (RODRIGUES, 2003, p. 115).

Verdade seja, o Estado para combater as organizações criminosas terá de limitar direitos fundamentais daqueles que por estarem nelas envolvidos fenecem com os direitos fundamentais dos demais cidadãos. Entre debilitar as garantias dos indivíduos entregues ao crime e comprimir às da sociedade, evidente que a primeira opção deva ser eleita, afinal os direitos daqueles jamais poderão ser exercidos em prejuízo dos desta, sob pena de se malograr a ordem pública que é de interesse de todos. Mesmo porque, não há direitos 
fundamentais e absolutos na sua efetivação, e o Estado de Direito exige igualmente a proteção de valores institucionais essenciais à sua própria sobrevivência, nomeadamente a viabilização de uma profícua administração da Justiça.

Sob esse entendimento também se debruça a jurisprudência do Egrégio Supremo Tribunal Federal (MS23.452/RJ. Relator: M inistro Celso de M ello. DJ 12.05.2000):

\begin{abstract}
Não há, no sistema constitucional brasileiro, direitos ou garantias que se revistam de caráter absoluto, mesmo porque razões de relevante interesse público ou exigências derivadas do princípio de convivência das liberdades legitimam, ainda que excepcionalmente, a adoção, por parte dos órgãos estatais, de medidas restritivas das prerrogativas individuais ou coletivas, desde que respeitados os termos estabelecidos pela própria Constituição. 0 estatuto constitucional das liberdades públicas, ao delinear o regime jurídico a que estas estão sujeitas - e considerando o substrato ético que as informa -, permite que sobre elas incidam limitações de ordem jurídica, destinadas, de um lado, a proteger a integridade do interesse social e, de outro, a assegurar a coexistência harmoniosa das liberdades, pois nenhum direito ou garantia pode ser exercido em detrimento da ordem pública ou com desrespeito aos direitos e garantias de terceiros. (grifo nosso).
\end{abstract}

Diante das considerações até aqui expendidas, imperioso se faz o reconhecimento da legitimidade da restrição dos direitos daqueles que, inseridos no mundo do crime organizado, devassam a ordem pública. Em razão das artimanhas das quais se valem para dificultar a persecução penal, medidas mais energéticas urgem ser empregadas.

Neste panorama surgem as medidas restritivas de direitos para impedir que a garantia dos direitos fundamentais torne-se ao criminoso um refúgio para prosseguir com suas práticas criminosas saindo ileso de qualquer punição.

Intolerável que os direitos e garantias fundamentais sejam desvirtuados a ponto de serem vistos pelo infrator da lei penal como beneplácito da impunidade.

Se é ponto incontroverso que o Estado deve adotar medidas restritivas de direitos frente à criminalidade organizada, lídima também é a afirmação de ele ter de atuar dentro de rígidos limites ao exercer o seu poder-dever punitivo, a fim de preservar a dignidade humana. 0 poder estatal não pode extrapolar o seu jus puniendi, de forma que, qualquer garantia, até mesmo a do réu, só pode ser restringida de forma excepcional e quando houver a estrita necessidade.

Assim, as garantias fundamentais hão de ser flexibilizadas sempre, em caráter excepcional e em casos extremamente graves, como o é o da criminalidade organizada. 


\section{Relativização de direitos fundamentais: uma abordagem a lume da necessidade da adoção de um tratamento constitucional penal diferenciado face à expansão desenfreada da criminalidade organizada}

Claro que o exercício de restrição de direitos não é ilimitado, só sendo justificado por motivos de adequação, necessidade e supremacia do "ente substancial" a ser tutelado em conflito com aquele a ser restringido.

À evidência, todos esses motivos são detectados ante a ululante propagação da macrocriminalidade.

Em primeiro lugar, nítida é a adequação, uma vez que a restrição de certos direitos de participantes dos grupos criminosos organizados possibilita alcançar o resultado pretendido, qual seja, a apuração dos crimes e a conseqüente efetivação da justiça ao se impedir a impunidade desta vasta gama de indivíduos afetos à delinqüência.

A necessidade também se faz presente para tornar mais branda a hegemonia dessas garantias, visto que, não há outra medida menos gravosa para promover o fim buscado.

Finalmente, a supremacia do bem jurídico a ser protegido salta aos olhos, pois entre a garantia de um direito do criminoso e a concreção da justiça penal com vistas à repressão da criminalidade organizada, lógico que esta deve preponderar.

De fato o Direito Penal só será cônscio em reprimir a criminalidade organizada na medida em que justapuser as garantias fundamentais num mesmo plano que 0 da sua eficácia. As garantias fundamentais só se justificam se forem interpretadas à luz da eficiência do direito Penal, pois o bom funcionamento da jurisdição penal resulta decisivo para assegurar a vigência prática das garantias em questão (DAUDET; FRONDIZ apud SILVA, 2003, p. 49-50).

Em epítome, a balança deve pender em favor dos interesses da sociedade, devendo o Estado para alcançá-los prover meios para a pacificação social e o resguardo dos direitos e liberdades públicas. Melhor sacrificar o direito de alguns (que inclusive, por estarem emersos na criminalidade já atentam contra os direitos alheios) do que sacrificar os direitos de toda a sociedade.

\section{Conclusão}

Para que o Direito Penal cumpra o seu papel de proteger os valores essenciais à subsistência harmônica do corpo social, imprescindível que para toda infringência da norma penal imposta haja uma sanção correspondente. Ou seja, o Estado ao avocar para si o 
monopólio da jurisdição, tem a obrigação de proteger os bens jurídicos eleitos como os mais importantes de qualquer lesão ou ameaça de lesão, já que, via de regra, o indivíduo não está autorizado a fazer justiça com as próprias mãos.

Em outros termos, quer-se dizer, que num Estado de Direito Democrático, a impunidade não pode ter vez, pois do contrário, o próprio Estado ao não aplicar o direito penal ao caso concreto estaria incutindo na consciência coletiva a pouca relevância que dedica aos valores sociais, afetando a credibilidade da justiça penal e fazendo com que a sociedade deixe de observar tais valores.

Em decorrência disso, as práticas criminosas levadas a cabo pelo crime organizado não devem ficar imunes à responsabilização penal, sob pena de se viciar o escopo do direito penal que não é outro senão a realização da pacificação social pela inadmissão da violação dos bens delineados como fundamentais para o convívio do homem em sociedade.

Ocorre, todavia, que não há como reprimir o crime organizado com os meios previstos no vigente Código de Processo Penal, que data de 1941, mais de meio século, portanto. Não há como se valer dos velhos instrumentos penais, que se mostram defasados em relação à sofisticação da criminalidade organizada. 0 crime se modernizou, mormente 0 crime organizado. Não pode a lei ficar inerte diante da realidade, como também não pode ficar estático seu intérprete, sob risco da sociedade ser engolida pela criminalidade.

Conclui-se que as características ínsitas à criminalidade organizada repercutiram na contemporânea dogmática penal, posto que, o tradicional modelo de tipificação e os clássicos instrumentos penais utilizados no tratamento da criminalidade individualizada se mostram obsoletos para o tratamento do fenômeno.

Apresenta-se, assim, a relativização de direitos fundamentais do acusado como preciosa arma de repressão aos grupos criminosos organizados, além de a apresentar como importante aliada para 0 enaltecimento da função de tutela de bens jurídicos promovida pelo Direito Penal, ao possibilitar o alcance do alto escalão de criminosos que raramente seriam responsabilizados não fosse ela.

Em apertada síntese, a flexibilização de direitos fundamentais dos envolvidos na criminalidade organizada tem o poder de minimizar a ignominiosa impunidade, já que é capaz de atingir criminosos que provavelmente escapariam à punição da lei penal por se acobertarem no manto da "lei do silêncio" das organizações criminosas e geralmente serem 


\section{Relativização de direitos fundamentais: uma abordagem a lume da necessidade da adoção de um tratamento constitucional penal diferenciado face à expansão desenfreada da criminalidade organizada}

detentores de elevado poder aquisitivo. E não é só. Por tudo o que foi tratado, aduz-se que, tal estratégia fortifica o fim do Direito Penal de possibilitar o jus puniendi do Estado toda vez que os bens jurídicos erigidos como mais importantes forem lesad os ou ameaçados de lesão.

Conveniente, pois, que ela seja usada, desde que com a devida cautela, de modo a evitar arbitrariedades, como ferramenta de promoção da segurança e da justiça, direitos estes que, de acordo com o preâmbulo da Lei Maior ${ }^{3}$, devem ser assegurados pelo Estado de Direito Democrático.

\section{Referências}

BARATTA, Alessandro. Criminologia crítica e crítica do direito penal: introdução à sociologia do direito penal. Tradução: Juarez Cirino dos Santos. 2 ed. Rio de Janeiro : Freitas Bastos: Instituto Carioca de Criminologia, 1999.

BARROS, Suzana de Toledo. O princípio da proporcionalidade e o controle de constitucionalidade das leis restritivas de direitos fundamentais. 3 ed. Brasília: Brasília Jurídica, 2003.

BARROSO, Luís Roberto. Interpretação e aplicação da Constituição: fundamentos de uma dogmática constitucional transformadora. 5. ed. São Paulo: Saraiva, 2003.

BATISTA, Nilo. Introdução crítica ao direito penal brasileiro. 8. ed. Rio de Janeiro: Revan, 2002.

BATISTI, Leonir. Curso de Direito Processual Penal. 2 ed. v. 2. Curitiba: Juruá, 2007.

BONAVIDES, Paulo. Curso de Direito Constitucional. 14. ed. São Paulo: Malheiros, 2004.

BORGES, Luiz Flávio D’ Urso. Direito Criminal na atualidade. São Paulo: Atlas, 1999.

BORGES, Paulo César Côrrea. O crime Organizado. São Paulo: Unesp, 2002.

CANOTILHO, J. J. Gomes. Direito Constitucional. 5. ed. Coimbra: Almedina, 1991.

CAPEZ, Fernando. Legislação Penal Especial: juizados especiais criminais, interceptação telefônica, crime organizado, tóxicos. 4. ed. São Paulo: Damásio de Jesus, 2005. v. 2.

30 preâmbulo da Carta Constitucional de 1988 anuncia que:

"Nós, representantes do povo brasileiro, reunidos em Assembléia Nacional Constituinte para instituir um Estado Democrático, destinado a assegurar o exercício dos direitos sociais e individuais, a liberdade, a segurança, o bem-estar, o desenvolvimento, a igualdade e a justiça como valores supremos de uma sociedade fraterna, pluralista e sem preconceitos, fundada na harmonia social e comprometida, na ordem interna e internacional, com a solução pacífica das controvérsias, promulgamos, sob a proteção de Deus, a seguinte CONSTITUIÇÃO DA REPÚBLICA FEDERATIVA DO BRASIL." (grifo nosSo). 
CASTANHEIRA, Beatriz Rizzo. Organizações criminosas no Direito Penal brasileiro: 0 estado de prevenção e o princípio da legalidade estrita. Revista Brasileira de Ciências Criminais, São Paulo, v. 6. n. 24. out./dez. 1998.

CAVALCANTI, Eduardo M edeiros. Crime e sociedade complexa: uma abordagem interdisciplinar sobre o processo de criminalização. 1. ed. Campinas: ZZN, 2005.

CHOUKR, Fauzi Hassan. Garantias constitucionais na investigação criminal. 3. ed. Rio de Janeiro: Lumen Juris, 2006. . Processo Penal de Emergência. Rio de Janeiro: Lumen Juris, 2002. . Temas de Direito e Processo Penal. Rio de Janeiro: Lumen Juris, 2004.

COSTA, Renata Almeida da. A sociedade complexa e o crime organizado: a contemporaneidade e o risco nas organizações criminosas. Rio de Janeiro: Lumen Juris, 2004.

ESPÍNDOLA, Ruy Samuel. Conceito de Princípios Constitucionais: elementos teóricos para uma formulação dogmática constitucionalmente adequada. 2. ed. São Paulo: Revista dos Tribunais, 2002.

FERNANDES, Antonio Scarance. Crime Organizado e a legislação brasileira. In: PENTEADO, Jaques de Camargo. Justiça Penal 3: críticas e sugestões. São Paulo: Revista dos Tribunais, 1995.

. Processo Penal Constitucional. 4. ed. São Paulo: Revista dos Tribunais, 2005.

. GOM ES FILHO, Antonio Magalhães; GRINOVER, Ada Pelegrini. As nulidades do Processo Penal. 7. ed. São Paulo: Revista dos Tribunais, 2001.

GOM ES, Luiz Flávio. Crime organizado: que se entende por isso depois da Lei 9.034/95? (Apontamentos sobre a perda da eficácia de grande parte da Lei 9.034/95). Disponível em: বttp://www.jus.br/doutrina/texto.asp? id=2919>. Acesso em: 25 mar. 2007.

. 0 Direito Penal na era da globalização. São Paulo: Revista dos Tribunais, 2002. (Série As ciências criminais no século XXI; v. 10.) - CERVINI, Raúl. Crime Organizado: enfoque criminológico, jurídico (Lei 9.034/95) e político-criminal. 2. ed. São Paulo: Revista dos Tribunais, 1997.

GRINOVER, Ada Pellegrini. Criminalidade moderna e reformas penais: estudos em homenagem ao Prof. Luiz Luisi. Porto Alegre: Livraria do Advogado, 2001.

GUERRA FILHO, Willis Santiago. Processo Constitucional e Direitos Fundamentais. São Paulo: Celso Bastos, 1999. 


\section{Relativização de direitos fundamentais: uma abordagem a lume da necessidade da adoção de um tratamento constitucional penal diferenciado face à expansão desenfreada da criminalidade organizada}

HASSEM ER, Winfried. Segurança pública no estado de direito. Tradução de Carlos Eduardo Vasconcelos. Revista Brasileira de Ciências Criminais, São Paulo, n. 5, jan./mar. 1994.

Público, 1993.

. Três temas de Direito Penal. Porto Alegre: Fundação Escola Superior do Ministério

LAVORENTI, Wilson; SILVA, José Geraldo da. Crime organizado na atualidade. Campinas:

Bookseller, 2000.

LIPINSKI, Antonio Carlos. Crime Organizado \& Prova Penal. Curitiba: Juruá, 2006.

LOPES, Inácio Carlos Dias; TENÓRIO, Igor. Crime Organizado. 1. ed. Brasília: Revista Consulex, 1995.

LUISI, Luiz. Os princípios constitucionais penais. Porto Alegre: Fabris, 1991.

M AIA, Rodolfo Tigre. 0 Estado desorganizado contra o crime organizado: anotações à Lei Federal no 9.034/95 (Organizações Criminosas). Rio de Janeiro: Lumem Juris, 1997.

M ENDRONI, M arcelo Batlouni. Crime Organizado: aspectos gerais e mecanismos legais. São Paulo: Juarez de Oliveira, 2002.

M IRABETE, Julio Fabbrini. M anual de Direito Penal. 17. ed. São Paulo: Atlas, 2003. v. 3. . Processo Penal. 14. ed. São Paulo: Atlas, 2003.

M OCCIA, Sergio. Emergência e defesa dos direitos fundamentais. Revista Brasileira de Ciências Criminais, São Paulo, n. 25. jan./mar. 1999.

ROBINSON, Jeffrey. A globalização do crime. Rio de Janeiro: Ediouro, 2001.

RODRIGUES, Anabela M iranda. Criminalidade Organizada - que política criminal? Revista Brasileira de Direito Comparado, Rio de Janeiro, n. 24, abr. 2003.

SALLES, Carlos Alberto de. Reforma penal e nova criminalidade. Revista Brasileira de Ciências Criminais, São Paulo, v. 3, n. 12, out./dez. 1995.

SANTOS, Juarez Cirino dos. Crime Organizado. Revista Brasileira de Ciências Criminais, São Paulo, v. 11, n. 42, jan./mar. 2003.

SILVA, Eduardo Araujo da. Crime organizado: procedimento probatório. São Paulo: Atlas, 2003. 
SILVA SÁNCHEZ, Jesús-M aría. A expansão do Direito Penal: aspectos da política criminal nas sociedades pós-industriais. Tradução de Luiz Otavio de Oliveira Rocha. São Paulo: Revista dos Tribunais, 2002.

SIQUEIRA FILHO, Élio Wanderley de. Repressão ao crime organizado: inovações da Lei 9.034/95. 2. ed. Curitiba: Juruá, 2003.

SWAANINGEN, René Van. Controle do crime no século XXI - Analisando uma nova realidade. Revista Brasileira de Ciências Criminais, São Paulo, v. 11. n. 42, jan./mar. 2003.

SZNICK, Valdir. Crime organizado. São Paulo: Livraria e Editora Universitária de Direito, 1997.

TOLEDO, Francisco de Assis. A modernização das Leis Penais. In: PENTEADO, Jaques de Camargo. Justiça Penal 3: críticas e sugestões. São Paulo: Revista dos Tribunais, 1995. . Princípios básicos de direito penal. 2. ed. São Paulo: Saraiva, 1986.

ZAFFARONI, Eugenio Raúl. Crime Organizado: uma caracterização frustada. Rio de Janeiro: Relume/Dumará, 1996. (Discursos Sediosos. Instituto Carioca de Criminologia; v. 1). 